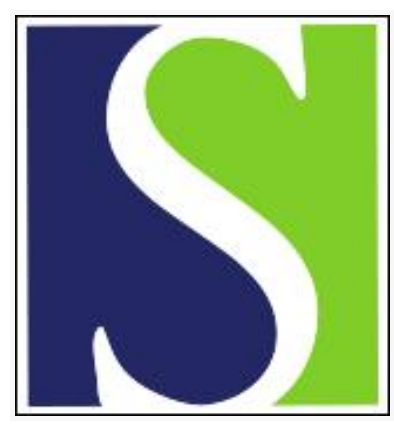

Scand J Work Environ Health 1982;8(1):77-79

https://doi.org/10.5271/sjweh.2492

Issue date: Mar 1982

Acute solvent-ethanol interactions with special reference to xylene.

by Riihimäki V, Laine A, Savolainen K, Sippel H

Key terms: acute solvent-ethanol interaction; carbon disulfide; dimethylformamide; ethanol; industrial solvent; $m$-xylene; metabolic interaction; short communication; solvent; trichloroethylene; xylene

This article in PubMed: www.ncbi.nlm.nih.gov/pubmed/7134927

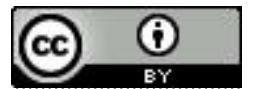


11. Tossavainen A. Styrene use and occupational exposure in the plastic industry. Scand $j$ work environ health 4 (1978): suppl 2, 7-13.

12. Vainio $H$, Pääkkönen $K$, Rönnholm $K$, Raunio- V, Pelkonen O. A study on the mutagenic activity of styrene and styrene oxide. Scand j work environ health 2 (1976)
$147-151$.

13. Vessey MP, Nunn JF. Occupational hazards of anaesthesia. Br med j 281 (1980) 696698.

Received for publication: 2 August 1981

\title{
Acute solvent-ethanol interactions with special reference to xylene
}

\author{
by Vesa Riihimäki, MD, MSc, ${ }^{1}$ Arto Laine, MD, ${ }^{1}$ Kai Savolainen, $M D,{ }^{2}$ \\ Helmut Sippel, $\mathrm{LPh}^{3}$
}

\begin{abstract}
RIIHIMÄKI V, LAINE A, SAVOLAINEN K, SIPPEL H. Acute solvent-ethanol interactions with special reference to xylene. Scand $j$ work environ health 8 (1982) $77-79$. Acute ethanol ingestion inhibits the metabolism of the common industrial solvents trichloroethylene and dimethylformamide. The solvents in turn may interact with ethanol metabolism as shown by an accumulation of acetaldehyde and occasional symptoms of alcohol intolerance. It was recently found that mutual metabolic interaction occurs even in the context of ethanol ingestion $(0.8 \mathrm{~g} / \mathrm{kg}$ in single dose) combined with subsequent inhalation exposure to $\mathrm{m}$-xylene $\left(6.0 \& 11.5 \mathrm{mmol} / \mathrm{m}^{3}\right.$ (140 \& $\left.280 \mathrm{ppm}\right)$, over $4 \mathrm{~h}$ ). Ethanol impaired the metabolic clearance of $\mathrm{m}$-xylene, raised the blood xylene concentration, and decreased the urinary excretion of methylhippuric acid. Thus, ingestion of ethanol is a noticeable source of error in the biological monitoring of xylene uptake. Some people appear to be susceptible to combined ethanol-xylene exposure and may develop nausea and dermal flush.
\end{abstract}

Key terms: carbon disulfide, dimethylformamide, ethanol, industrial solvents, metabolic interaction, trichloroethylene, m-xylene.

Alcoholic beverages are extensively consumed in many countries, occasionally during the workday and particularly after the workhours. In view of the fact that a share of solvents taken up by the human body is slowly excreted, it is obvious that the simultaneous occurrence of ethanol and solvents in the tissues of solvent-exposed workers is not uncommon.

1 Department of Industrial Hygiene and Toxicology, Institute of Occupational Health, Helsinki, Finland.

2 Department of Pharmacology, University of Helsinki, Helsinki, Finland.

3 University of Forensic Chemistry, Helsinki, Finland.

Reprint requests to: Dr V Riihimäki, Institute of Occupational Health, Haartmaninkatu 1, SF-00290 Helsinki, Finland.
Ethanol is known to inhibit drug metabolism acutely $(14,15)$, and to stimulate drug metabolism through microsomal induction when administered repeatedly (6, $7,15)$. Thus the effects of ethanol on solvent metabolism may be complex, depending on the timing and frequency of ethanol ingestion. In this communication we want to call attention to the immediate metabolic consequences following ethanol ingestion in the context of solvent exposure, as reported in the literature and observed in our own studies.

\section{Ethanol-mediated changes of solvent metabolism}

Molar concentrations of ethanol in blood after social drinking are at least $100-200$ 
times higher than molar blood solvent concentrations during relevant occupational exposures, and the concentration difference is still much larger after the termination of solvent exposure. Therefore, on the mere basis of concentration difference it can be expected that ethanol may primarily affect solvent metabolism rather than solvents affecting ethanol metabolism.

By virtue of the competitive inhibition of alcohol dehydrogenase, ethanol blocks the metabolism of methanol (9) and ethylene glycol (12) to toxic metabolites. The microsomal metabolism of inhaled dimethylformamide was inhibited by large ethanol doses in animals (3). Human studies have shown that a moderate ingestion of ethanol in combination with a simultaneous exposure to trichloroethylene $[2.0 \&$ $4.0 \mathrm{mmol} / \mathrm{m}^{3}$ (50 \& $100 \mathrm{ppm}$ ), respectively] resulted in a complex metabolic interaction (10). Ethanol raised blood trichloroethylene concentrations by about two- to threefold, a result suggesting that metabolic clearance of trichloroethylene via microsomal oxidation had decreased, and no formation of the end metabolite, trichloroacetic acid, was observed as long as the blood ethanol concentration remained high (10).

Similarly, we found that the ingestion of a moderate dose of ethanol $(0.8 \mathrm{~g} / \mathrm{kg})$ prior to 4-h inhalation exposures to $\mathrm{m}-\mathrm{xy}-$ lene $\left[6.0 \& 11.5 \mathrm{mmol} / \mathrm{m}^{3}(140 \& 280 \mathrm{ppm})\right]$ raised the blood xylene level by about 1.5to 2.0-fold and decreased urinary methylhippuric acid (the predominant end metabolite) excretion by about $50 \%$ in comparison to identical xylene exposures without ethanol (13). In this case too the mechanism of ethanol-xylene interaction was presumably the ethanol-mediated inhibition of microsomal xylene metabolism. Whether ethanol-induced disturbances of solvent metabolism per se could aggravate solvent hazards is not readily answered in light of current knowledge. However, this phenomenon may be an important source of methodological error in the biological monitoring of solvent uptake.

\section{Solvents and acute ethanol intolerance}

The reverse aspect of metabolic solventethanol interactions, ie, disturbances of ethanol metabolism caused by solvents, seems to have the potential for a considerable subjective nuisance if not that of a hazard. Inhalation exposure to trichloroethylene (16), carbon disulfide (2), and dimethylformamide (8), followed by ethanol ingestion, is known to cause unpleasant symptoms of intolerance such as facial flushing and occasional dizziness. Under certain experimental conditions these compounds have disturbed ethanol metabolism and increased blood acetaldehyde levels $(4,5,10)$. This effect on blood acetaldehyde was even more pronounced when the ethanol challenge was given $16-24 \mathrm{~h}$ after the solvent exposure $(4,5)$. Symptoms of alcohol intolerance have also occurred for several days (8) and even weeks (16) after solvent exposure. The administration of acetaldehyde causes a dermal flush, hyperventilation, and tachycardia in man (1). Thus, understandably, the solvent-induced symptoms of ethanol intolerance have generally been attributed to the cumulation of acetaldehyde.

We recently observed that the ingestion of ethanol $(0.8 \mathrm{~g} / \mathrm{kg})$ prior to 4 -h inhalation exposures to $\mathrm{m}$-xylene $\left[\begin{array}{lll}6.0 & \& & 11.5\end{array}\right.$ $\mathrm{mmol} / \mathrm{m}^{3}$ (140 \& $\left.\left.250 \mathrm{ppm}\right)\right]$ made one subject out of ten feel dizzy and nauseated during the exposure to the lower xylene level, and the same person, plus an additional subject, was overcome by similar symptoms at the higher level. Ethanol ingestion alone or pure xylene exposure did not cause such symptoms. No signs of dermal flush were discovered. During an exposure to the higher xylene concentration following ethanol ingestion, the blood acetaldehyde concentration was transiently elevated, whereas the elimination of ethanol in the blood was not discernibly affected (13). Furthermore, in another as yet unpublished study in which eight volunteers ingested the same dose of ethanol at the end of a 4-h m-xylene exposure $\left[12.3 \mathrm{mmol} / \mathrm{m}^{3}(300 \mathrm{ppm})\right]$, one subject developed a conspicuous dermal flush on his face, neck, and the upper parts of his chest and back. He exhibited slight erythema of the cheeks even after ethanol alone. The volunteers experienced no other untoward symptoms, and in this case a rise of blood acetaldehyde could not be demonstrated.

In our experience the combination of 
alcohol ingestion and inhalation exposure to xylene, a common solvent in paints, glues, printing inks, pesticides, etc, may cause unpleasant symptoms in some susceptible individuals. These can be manifested as dizziness and nausea or dermal flush, perhaps depending on the relative concentrations of the two compounds and their metabolites in the body. The role of acetaldehyde in the causation of intolerance symptoms is an uncertain if tempting speculation. Individual susceptibility could be associated with a genetic sensitivity to ethanol, which presents similar symptoms (17). Since xylene is metabolized to a toxic aldehyde, methylbenzaldehyde (11), its possible role should also be investigated.

\section{References}

1. Asmussen E, Hald J, Larsen V. The pharmacological action of acetaldehyde on the human organism. Acta pharmacol toxicol 4 (1948) $311-320$.

2. Djuric D. Some aspects of antabuse, carbon disulphide and ethyl alcohol metabolism. Arch hig rada 22 (1971) $171-177$.

3. Eben A, Kimmerle G. Metabolism studies of $\mathrm{N}, \mathrm{N}$-dimethylformamide. Int arch occup environ health 36 (1976) 243-265.

4. Freundt $\mathrm{KJ}$, Lieberwirth $\mathrm{K}$, Netz H, Pöhlmann E. Blood acetaldehyde in alcoholized rats and humans during inhalation of carbon disulphide vapor. Int arch occup environ health 37 (1976) 35-46.

5. Hanasono GK, Fuller RW, Broddle WD, Gibson WR. Studies on the effects on N,N'-dimethylformamide on ethanol disposition and on monoamine oxidase activity in rats. Toxicol appl pharmacol 39 (1977) $461-372$.

6. Iber FL. Drug metabolism in heavy consumers of alcohol. Clin pharmacol ther 22 (1977) $735-742$.
7. Ishii H, Joly JG, Lieber CS. Effect of ethanol on the amount and enzyme activities of hepatic rough and smooth microsomal membranes. Biochim biophys acta 291 (1973) $411-420$.

8. Lyle WH, Spence TWM, McKinneley WM, Duckers $K$. Dimethylformamide and alcohol intolerance. $\mathrm{Br} \mathrm{j}$ ind med 36 (1979) $63-66$.

9. Makar AB, Tephly TR, Mannering GJ. Methanol metabolism in the monkey. Mol pharmacol 4 (1968) 471-483.

10. Müller G, Spassowski M, Henschler D. Metabolism of trichloroethylene in man: III Interaction of trichloroethylene and ethanol. Arch toxicol 33 (1975) 173-189.

11. Patel JM, Harper C, Drew RT. The biotransformation of p-xylene to a toxic aldehyde. Drug metab dispos 6 (1978) 368374.

12. Peterson DI, Peterson JE, Hardinge MG, Wacker WEC. Experimental treatments of ethylene glycol poisoning. J am med assoc 186 (1968) 955-957.

13. Riihimäki V, Savolainen K, Pfäffli P, Pekari K, Sippel HW, Laine A. Metabolic interaction between m-xylene and ethanol. Arch toxicol (in press).

14. Rubin E, Gang H, Misra PS, Lieber CS. Inhibition of drug metabolism by acute ethanol intoxication: A hepatic microsomal mechanism. Am j med 49 (1970) 801-806.

15. Rubin E, Lieber CS. Hepatic microsomal enzymes in man and rat: Induction and inhibition by ethanol. Science 162 (1968) $690-691$.

16. Stewart RD, Hake CL, Peterson JE. "Degreasers' flush": Dermal response to trichloroethylene and ethanol. Arch environ health 29 (1974) $1-5$.

17. von Wartburg J-P. Comparison of alcohol metabolism in humans and animals. In: Eriksson K, Sinclair JD, Kiianmaa K, ed. Animal models in alcohol research. Academic Press, London 1980, pp 427-443.

Received for publication: 16 October 1981 